\title{
Tears of Testimony: Glenn Beck and the Conservative Moral Occult
}

\author{
Scott Loren
}

[...] moral consciousness must be an adventure, its recognition must be the stuff of heightened drama.

- Peter Brooks, The Melodramatic Imagination

On 15 October 2009, the talk show host Glenn Beck cried on national television. ${ }^{1}$ Of course, crying on television is nothing new. Think of the tears shed on daytime soaps; think of Oprah. Beck's tears, however, were shed neither on a soap opera nor on Oprah. This spectacle of suffering took place on an evening news program available to over one hundred million US households. He was moderating the program, as he had been every night for nearly a year. While there may always be occasion to cry given the general content of the nightly news, more disorienting than a newscaster crying on national television was the proclaimed reason for Beck's tears: namely, nostalgia for simpler times in America. In the sense used here, the notion of America elicited by the word "America" refers not to the continental geography known as America, nor simply to the United States of America in its physical, political and historical specificity, but to a fantasmatic projection at once bound to material and historical specificity while also free from it. It is to this impossible space of an always-already lost innocence or wholeness that Beck wishes to return: an other space conceptually structuring the setting and giving form to a plotting of historical events in a dramatic story of innocence lost and, potentially, regained.

In the span of Beck's first year with Fox Television, as well as those to follow, it was not unusual for the moderator to become visibly agitated. Being moved to tears, though, had yet to become a fixed part of his repertoire. On this particular evening, Beck's tears were prompted and aesthetically punctuated by an old Kodak commercial staging a middle-class, ethnically discrete, suburban American familial idyll stylized as being from the $1950 \mathrm{os}$ and 1970s, and accompanied by Paul Anka singing "Times of Your Life." That is to say, what purportedly drove Beck to tears had nothing to do with the inhumane misadventure that all too often characterizes the spectacle of suffering in news media. It was an advertisement staging a cliché of 
nostalgia intended to evoke the sensation of nostalgia in its audience that had done the trick. Suspect as this may seem, Beck's strategy of tears has brought him enormous fame as a media personality; and though his strategy of tears may serve to discredit him amongst his detractors, it also has the opposite effect for a broad segment of the viewing public. Who is Glenn Beck, you might ask, and why has he been crying all over the American mass-media-sphere?

Looking back at American talk radio and television during the first decade of the 2000s, for better or for worse one will inevitably be confronted with the figure of Glenn Beck. His launch into mainstream popularity started with The Glenn Beck Program, first aired on AM radio in 2000 from Tampa, Florida. While the afternoon timeslot that he had taken over was trailing (eighteenth) in local ratings, the new moderator pushed the program to number one within its first year on the air. This local radio success opened up other opportunities for Beck. By 2002 he had a nationwide broadcast featured on 47 different stations. Within six years, Beck was broadcast on over 280 stations nationwide to some six-and-a-half million daily listeners. ${ }^{2}$ In 2008, the National Association of Broadcasters awarded Beck the Marconi Radio Award for Network Syndicated Personality of the Year. ${ }^{3}$ Beck had become a household name, and not only on the airwaves. In 2006 he took over a prime-time slot on CNN's Headline News, a Time Warner news channel broadcasting since 1982. In the new medium of the televisual, Beck once again gained ratings rapidly, and within two years Headline News had become the channel's second-most-watched program.

Established via the dual-platform programming of cable television and national talk radio, Beck soon became one of the most well-known conservative news-media personalities of all time. His radio show, The Glenn Beck Program, has garnered some of the highest ratings in radio since its first national broadcast in 2002. ${ }^{4}$ At the height of its popularity, his televised show, Glenn Beck, reached a viewership of over three million on a single evening. Beck has also authored six The New York Times bestseller books, making him a one-man mass-multi-media phenomenon. One might ask how crying on national television can facilitate such success. It had worked for Oprah. Indeed, in many respects Beck has inherited Oprah's tradition of subjective sentimentalism and the aesthetic spectacle of suffering that is inextricable from contemporary American media practices. But where Oprah captured the heart of America with teary daytime confessionals that encouraged individuals to find their true selves and realize their full potential, Beck's specialty is an admixture of anti-government, antihumanitarian, racist, polemical right-wing politics, farcical conspiracy 
theories and a hyperbolic melodramatic style. If you were wondering when a backlash to Oprah's philanthropic spiritual uplift and to a short era of affirmative racial mixing and queerness on primetime television would hit mainstream media, it did so with Beck.

If Oprah's "therapeutic style" and the tears it evoked seemed to make sense in its mass appeal to daytime television audiences, ${ }^{5}$ Beck's detractors have often had a hard time coming to terms with his hijacking of the evening news through a strategy of tears. Logically, many of his detractors point to the shoddiness of his One-World-Government and communist takeover theories, as well as to the wild inaccuracy of the self-proclaimed so-called faction that he presents on his show, but these critiques miss the point of what has made Beck so appealing. If it seems sheer madness to claim, for example, that "Jesus doesn't want a cap-and-trade system," or that Sen. Joseph McCarthy "was right," or to equate Al Gore with Hitler or Barack Obama with Satan, it is precisely the madness of Beck's method that sells. Despite having occupied the media space of what is ostensibly news, where listeners and viewers might expect a habitus of something that strives toward an objective presentation of perspectives on historic events, or may have been conditioned to believe that this is where so-called facts are presented, Beck's spectacular dramas do not deal in facts. They deal in feelings.

In the plotting of affective structures linked to non-inclusive modes of national identity, Beck's economy of emotion is evident at every turn. When he speaks to a cheering crowd of thousands in Norfolk, Virginia, about the world as they know it coming to an end in ten years' time, the superfluity of approximating fact in his rhetoric becomes wholly evident. His rhetorical and aesthetic strategies have been effective due to their efficiency in tapping strong objectless feelings such as anxiety or nostalgia and emotively anchoring them to objects of distrust and resentment. Rather than being problematic, the condition of nostalgic longing as attached to a phantom of a non-existent past serves Beck's melodramatic purpose, where a reflexive sense of hope is concomitantly sustained through and frustrated by sabotaging that which it purports to strive for as its goal. ${ }^{6}$

Beck's particular emotive economy is also reflected in the social issues, cultural myths and abstract associations that he links together: big government, progressivism, the national debt, the federal reserve, religion, gun control, libertarianism, the Holocaust, National Socialism, Stalinism, Marxism, socialism, communism and community organization, the last of which Beck effortlessly equates with those preceding it. "Social and ecological justice," Beck has been known to say, is "bullcrap.” Perturbing 
as it may be to ascribe reason or grant recognition to Beck's popularity, or affectively to digest his fear-mongering, hate-crime-inducing and racist politics, my purpose here is not to discredit nor attack Beck; at least, not in the first instance. Rather, I wish to make clear the extent to which Beck's operative mode is melodrama.

Melodrama studies is an area of research that has traditionally been a sub-category of genre studies via literary and film studies, but one that, as this volume evinces, is increasingly employed in sociological contexts to analyze a range of cultural phenomena and historical events, such as race relations or the representation of national trauma in the media. ${ }^{8}$ Peter Brooks describes the cultural advent of melodrama in relation to the secularization that occurred as a reaction to the social upheavals following the French Revolution. ${ }^{9}$ The Enlightenment's critique of religious and other institutions led to a radical displacement of hierarchies that had formerly legitimated moral code systems and provided a worldview with clearly accessible notions of good and evil. The destabilization of clerical and monarchic authority thus obfuscated "moral legibility," according to Brooks. Beyond the various practical causes that facilitate melodrama's prominence as a popular dramatic form (from laws regarding the use of language in public entertainment to social effects of rural displacement and urban growth), its extra-generic status, constituting a cultural mode or ontological lens, has to a considerable degree been ascribed to its ability to rehabilitate a system of Manichean moral codes that lends deeper meaning to action and being by grounding them in what Brooks termed "the moral occult." ${ }^{10}$

With secular modernity, melodrama fills an important gap: "It comes into being in a world where the traditional imperatives of truth and ethics have been violently thrown into question, yet where the promulgation of truth and ethics, their instauration as a way of life is of immediate, daily, political concern." ${ }^{11}$ Here we find a clear connection to Beck's political strategy and rhetorical style. His primary concern, as he has so often intimated, is to expose the Good and the Bad by promulgating hidden truths about unethical practices, policies and agendas on the left. The good conservatives of Beck's "Real America" are in the greatest danger of becoming the victims of liberal villainy. The urgency of his claims is evinced through his end-oftimes rhetoric: it is not about gaining or losing House majority, but rather about life and death. The truth that can save you, Beck claims, is lurking just beneath the appearance of things and is in dire need of exposure.

Melodrama, as Brooks perceived it, is achieved through a narrative exertion of pressure "upon the surface of things," turning the "banal stuff 
of reality" into "an exciting, excessive, parabolic story." ${ }^{12}$ This story is characterized by hyperbolic figures of villainy and virtuousness, and by monopathic moral polarization between good and evil, in which the villain "betrays and undoes the moral order" through "plotting, evil, [and] conscious obfuscation., ${ }^{13}$ The strong pathos induced by the virtuous victim's loss incites the necessity of action that will restore honor and the moral order. Elisabeth Anker has argued that the central characteristics of stage and screen melodrama can and do migrate into popular non-fiction contexts, such as political rhetoric. Synthesizing various central characteristics of melodrama as articulated by theorists such as Brooks, Thomas Elsaesser and (most prominently in the following) Linda Williams, Anker enumerates five distinctive qualities of melodrama:

(a) a space of moral virtue signified by pathos and suffering and increased through heroic action;

(b) the characters of a ruthless villain, a suffering victim, and a heroic savior who can redeem the victim's virtue through an act of retribution (the latter two can be inhabited in one person: the virtuous victim/hero);

(c) dramatic polarizations of good and evil;

(d) a cycle of pathos and action;

(e) the use of images, sounds, gestures and nonverbal communication to illuminate moral legibility as well as to encourage empathy for the victim and anger toward the villain. ${ }^{14}$

Through the various functional means (thematic, temporal and aesthetic), ${ }^{15}$ all elements serve to make a position of moral integrity easily identifiable, thus emotionally and ideologically aligning the viewer with the victim, who is both virtuous and righteous by dint of having been made a victim. Melodrama "is a discursive practice that makes truth and justice legible by demarcating a clear boundary between right and wrong, ${ }^{116}$ echoes of which can be found in Beck's repeated partisan claim that "it's not about left and right, but right and wrong." Such reductive and inclusive statements are typical of Beck's rhetorical style. When Anker claims that "the precise 'sublimity' of melodramatic rhetoric" is achieved through "the emphatic articulation of simple truths and relationships, the clarification of the cosmic moral sense of everyday gestures," Beck's rhetorical style, conceptual content and sought effect will easily be recalled.

Using melodramatic aesthetico-narrative techniques and temporal structures, Beck plots a story pattern that he repeatedly mobilizes. First, the public is turned into victims. There are many ways in which this is achieved, 
but Beck's core narrative is that the "Real America" he repeatedly refers to has lost its innocence, having strayed at times but more importantly having been taken advantage of or cheated on the sly by evil villains who want at all costs to destroy the nation; and indeed have nearly done so. The villains are democrats and social institutions; the biggest villain of all is President Obama. As a loyal citizen, a patriot and an individual who is able to see the truth behind the lies where others cannot, it is Beck's duty to expose the horrible inequities and those who perpetrate them to his public, who at the end of the day are good honest Americans who have fallen victim to the evil lurking amongst them. Naturally, exposing the hidden truth is of utmost urgency, but this alone cannot save the good people of Real America. Like any unwitting victim besieged by evil forces, Real America needs to be rescued before all is lost; and a rescue requires a hero.

Within Beck's fundamental plotline sketched here, characteristic elements of melodrama become explicit: the triad of villains, victims and heroes; the space of domestically localized lost innocence; tyranny and moral corruption; heightened pathos; the urgency of action; occulted knowledge and an aesthetically articulated, hyperbolically punctuated moral legibility. However, unlike the tradition of social melodrama where the masses are united against a powerful few, Beck's melodrama of a Real America does not divide those masses from their inequitable leaders, but rather divides both governing bodies and the masses internally along party lines, setting them vehemently against themselves. The unfortunate result is visibly reflected on a larger social scale, where democratic (and here I refer to the system of democracy, not the political party) political procedures are made lame through vindictive partisan acts of obstruction. The relationship between sentimentality and melodrama is important in this context. Where social melodrama can position the masses in a sentimental state of suffering together (or commiseration) that validates the victim position as virtuous, belligerently setting the masses against one another disperses evil, as opposed to localizing it. Thus the mechanism by which moral legibility triggers a pathos/action relay becomes overloaded, producing a "residue of unruly emotion that cannot be accounted for" properly, ${ }^{17}$ but that can be harnessed for other purposes; which is to say, a residue that might be redirected with intention.

Where Beck's politics might be described as an admixture of conservative ideals, libertarian ethics and Mormon theology, his peculiar style and the hyperbolic mythical figures that haunt his conceptual universe are all conjoined with uncanny ease under the generic formulas of melodrama: ill-willed socialists seeking national destruction and world domination 
versus morally upright, gun-toting, white, working-class "Real Americans" standing on the shoulders of the Founding Fathers. ${ }^{18}$ Three examples from Beck's repertoire illustrate the extent to which Beck employs the melodramatic mode: his attacks on Barack Obama, his "Restoring Honor" rally in Washington, and, of course, his televised strategy of tears.

In the Beck universe, there are many villainous hats that President Obama might wear for the construction of a melodramatic victim-villain paradigm. But in order to generate the negative national pathos that Beck seeks, the very embodiment of evil in the American imagination is required. Within the social imaginary, no other historical figure can call up associations of evil like the figure of Adolf Hitler. He is set apart from the common lot of murderous dictators who have made ethnic cleansing their daily business. If there were anything like a close second in the scale of metaphysical evil to the conservative American mind, this would be communism, the Red Scare. Beck draws on affective and iconic cultural memories of Hitler and Stalin, harnessing and redirecting these messy residual traces toward Obama. In his wild equations of Stalinist communism, National Socialism and American social services, Beck facilely interchanges a modern history of fascist regimes with American democratic ideals and community-building social practices in the public sector. He has likened Obama's healthcare reforms and expansion of AmeriCorps ${ }^{19}$ to conditions in Stalin's Soviet Union and Hitler's Third Reich. In Beck's nationalist melodrama, Obama is a "socialist" with "Marxist tendencies," "marching us to a non-violent fascism" that is to blame for "the destruction of the West. ${ }^{20}$ In a segment called "Comrade Updates," Beck showed images of White House policymakers with Hitler and Stalin mustaches painted onto their faces, claiming "I'm going to show you how these things [...] happening today line up with some of the goings-on in history's worst socialist, fascist countries." ${ }^{\prime 21}$ In another segment showing images of Obama and the then British Prime Minister Gordon Brown opposite Hitler and Stalin, Beck declares: "those who don't know history are destined to repeat it." Of course, there is no attempt to provide accurate historical information, nor even something vaguely resembling a logical or reasonable argument. It is not even narrative coherence that Beck's circus of signs seeks, but rather a kind of affective knee-jerk reaction: an overloading or stoppage of the signifying process, in which incongruent iconic images are knotted together in an associative, non-logical figuration of past horror and present anxiety. This is melodrama at both its best and worst. It achieves the linguistically inarticulable production of an affectively charged, morally resonant sign through a hyperbolic, punctuated aesthetic field, vibrant with surface tensions, on the one hand, while on the other, 
inciting fear that divides the masses in bitter resentment as opposed to uniting them in a common cause.

While the melodramatic gesture of comparing Obama to Stalin and Hitler might constitute a hyperbole hyperbolized, reaching dizzying new melodramatic heights, this is not the only cape of villainy that Beck has reserved for the United States' first black president: Obama is also a racist. Linda Williams has shown how a tradition, both fictional and non-fictional, of black vs. white racial melodrama is inseparable from race discourses in American culture. Although melodrama has a "propensity to side with the powerless, ${ }^{\prime 22}$ Williams points out that it has also been "employed by resentful whites whose own sense of powerlessness dangerously exaggerated the perception of a black threat to white hegemony."${ }^{{ }^{23}}$ Beck mobilizes this melodramatic scheme, playing a race card that frames his so-called "real" America as victims of a villainous, extremely dangerous "black man in the White House":24 "The president has, I think, exposed himself as a guy, over and over and over again, as a guy who has a deep-seated hatred of white people, or the white culture, I don't know what it is." ${ }^{25}$

The US journalist and author Alexander Zaitchik has suggested that in order to understand Beck's particular brand of racism, you first have to understand what he means by "the white culture." This "white culture" is synonymous with "an entire moral, political, and cultural universe, which Beck [...] has nicknamed the Real America. ${ }^{\text {"26 }}$ Beck's myth of a "Real America" is "at once geographic and non-geographic, racial and nonracial, real and imaginary," and is inextricably rooted in the mythology of an American heartland: primarily white, working-class, rural Middle America where Christian values and conservative morals supposedly dominate. ${ }^{27}$ The cultural associations with an American heartland inevitably evoke imagined nostalgic projections of national innocence for those who can relate positively to the cultural and racial hegemony that Beck promotes. Conceptually, Beck's Real America is juxtaposed with a villainous "fake America" that is "urban, socialist, godless, educated with all the wrong ideas [...] By threatening to overwhelm and extinguish the Real America, the fake is hostile in every way: anticapitalist, antifamily, and - the part of the triad that usually dares not speak its name - antiwhite. ${ }^{{ }^{28} 8}$ Beyond his racist claims that Obama's policy is prompted by a desire for slavery reparations, and his support of conspiracy theories that paint Obama as an insidious foreigner lacking the possession of legitimate US citizenship, Beck's particular style of playing the melodramatic race card is interesting in its coupling of racial demonization with the threat to a space of national innocence. Beck's Real America and American heartland constitute his 
fantasmatic melodramatic space of innocence to which his audience can only wish to return. It is the very wish of returning to an originary space of innocence that drives melodramatic pathos and the subsequent action needed to restore the virtuous victim's honor.

On 28 August 2010, nearly 100,000 people gathered in Washington DC at the Lincoln Memorial to celebrate America's "heroes and heritage." ${ }^{29}$ The tone of Beck's "Restoring Honor" rally was both spiritual and patriotic, encouraging Americans to unite in their belief in God, to honor war veterans, and to recall and return to the core American ideals as represented by the Founding Fathers. Purportedly, Beck's original intention was to hold a political rally to introduce his hundred-year "plan to save America," which he would outline in detail in an upcoming book, The Plan.$^{30}$ As a political ticket would have made taxable the charity funding he intended to raise, the rally assumed an apolitical appearance and the funds raised would partially go to the Special Operations Warrior Foundation, a non-profit organization that provides scholarships for children of Special Operations officers killed in service. ${ }^{31}$ The shift was one from a promise to rehabilitate lost innocence and virtue to one focusing on reparations for victims. Employing this particular structure of victimhood guarantees patriotic pathos and action constructed around the space of lost familial (i.e. domestic) innocence. Beck's original intention to "restore America and restore her honor"32 on this particular date creates a very peculiar constellation of Manichaean black vs. white racial melodrama.

There are few sound bites in US history that are as prominent in memory and emotionally resonant as Martin Luther King Jr.'s "I have a dream." These four words from his speech at the 1963 March on Washington for Jobs and Freedom have been a potent cultural artifact in the history of civil rights, racial equality and national identity. In choosing the anniversary and exact location of King Jr.'s address, Beck's rally to "restore honor" was guaranteed a high level of emotive cultural resonance, but a resonance that is necessarily conflicted. It draws from the emotive well of sympathy within and with the African American community while at the same time "restoring" the date to predominantly white American conservatives by symbolic usurpation. If Beck was unable to capitalize on the proclamation of having a dream himself - no doubt the aim of presenting his hundred-year plan at this particular time and place - this was not an end to his "attempt to flip the imagery of Dr. King. ${ }^{33}$ His tactic here is similar to the one seeking to imbue the image of Obama with an association to fascism, but temporally and axiologically inverted. Where "Comrade Updates" recalled troubling images from the past to destabilize and haunt the present in an aesthetically punctuated visual 
field, the melodramatic rally call to "restore honor" constituted a troubling choir of voices from the present that might rattle the bones of the past and chase them (for some, at least) from memory. With such a platform for co-presenter Sarah Palin's vice-presidential nomination and for what would come to be known as the inaugurating event of the Tea Party, nowhere else would this kind of socio-political, ideological and historical usurpation find such a receptive audience. The implications of restoring honor are thus two-fold, both melodramatic and both racially significant. First, there is the longing for a former innocence; next, we find the production of a pathos/ action relay fueled by Manichaean oppositions of good/evil, victim/villain and white/black. According to Beck, regaining honor means a nostalgic return to a set of ideologies personified in US cultural mythology by the "founding fathers" whom Beck idolizes (in a literal sense); a time in which slavery was integral to the organization and material practices of social life in America. Symbolically, this necessitates a retroactive, fantasmatic construction of history in which Beck's "Real [White] America" has fallen victim to the illicit appropriation of civil rights by an Imposter America, an illegitimate dark charlatan America that, in the end, even manages to seize and occupy the White House.

Theories of melodrama explain that the archetypal victim-villain-hero triad functions to elicit pathos and action by legitimation through the "felt truth" of the moral occult. The felt truths to which Beck appeals through his rhetoric of virtuous victimhood and his strategy of tears, however defamatory and racist they may be, seek affirmation in an index of deeper moral values. Recourse to a register of morality in Beck's Restoring Honor rally is mirrored in the event's religious and conservative overtones, creating a dense layer of racial, religious and partisan melodrama, where a Manichaean split between good, God-fearing, conservative, white virtuous victims and evil, heathenish, democratic, dark degraded villains further polarizes and emotionally charges partisan politics in America. Evacuating any necessity for logos and centralizing pathos, polarization and emotive intensification through reference to a moral occult is precisely what is at stake in Beck's strategy of tears. The mute aesthetic hyperbole of melodramatic tears serves to make moral truths legible. When Beck cries for love of his country, the gesture is one of authentication: his virtuous tears of suffering are evidence of his moral credibility and the verity of his claims - emotionally at least, but that is what counts. It is worth noting that while discovering the emotive potential of melodramatic rhetoric in political debate, Beck also discovered his affinity to Mormonism, where the shedding of tears is common in the rituals of revelation. A man moved to tears by faith is a man testifying to 
the power of his convictions. ${ }^{34}$ In Mormonism as in melodrama, "moral consciousness must be an adventure, its recognition must be the stuff of heightened drama. ${ }^{{ }^{35}}$ Placing Beck and his mass appeal in a media-specific cultural genealogy thus also means contextualizing them within a tradition equally known for its hyperbolic punctuated aesthetic, a Manichaean rhetoric of evil versus good, dark versus light, and of victimhood, virtue and redemption.$^{36}$ Counterpoised (though not contradictory to) his strategy of tears, Beck's brash dogmatic tone descends from that many-headed hydra at the gates where bizarre Americana and mass media meet: televangelism, itself deeply imbricated in the American melodramatic mode. Beck is at once a quintessentially American media-affect event and cultural artifact. Pandering to feelings of being overwhelmed by the irreducible complexities of contemporary social existence, of constituting the demos in a perpetual state of national emergency, he is both a symptom and etiological condition of his times. If Beck's strategy of tears evinces the protean capacity and prominence of a melodramatic mode in American culture, it also troublingly reframes the question of what melodrama's aesthetic strategies can tell us about the ideological discourses that contain or mobilize them.

Lauren Berlant has proposed a theory of "cruel optimism" to describe the juncture of affect, mediation and ideology that has come to characterize contemporary American sensibilities. Her theory can help explicate the emotive reflexes and discursive logics at play in Beck's public spectacle of affective moral conviction via cultural archetypes such as melodrama, Mormonism, a "real America," the heartland or the founding fathers. She proposes cruel optimism as an "affectively stunning double bind" in which there are passionate attachments to (A) fantasies that ultimately function as obstacles to that which they purportedly seek as their goal, and to (B) the optimistic hope of fulfillment that such fantasies falsely represent. The cruelty of cruel optimism, she claims,

is apprehensible as an effective event in the form of a beat or a shift in the air that transmits the complexity and threat of relinquishing ties to what's difficult about the world. What remains, therefore, is to specify how the activity of affective attachment can be located formally in a historical, cultural, and political field in ways that clarify the process of knotty tethering to objects, scenes, and modes of life that generate so much overwhelming yet sustaining negation. ${ }^{37}$

Perhaps there is also a sustaining reflexivity structuring the relation between Berlant's cruel optimism and the cultural myth of melodrama. 
On the one hand, a cultural sensibility of cruel optimism might be viewed as facilitating the structural contingencies of melodrama. At the core of any if I could just ... then everything would be alright, good, like it used to be logic is a nostalgic fantasy of utopic wholeness, which in turn necessitates systems of classification that will allow feelings to be attached to objects and thus be transformed into emotions. A feeling of frustration or discontent might be directed toward an individual or institution, thus establishing an obstacle. Obstacle status allows an object to refine amorphous discontent into something more discrete and local, something like contempt, for example, which in turn renders a greater degree of stasis in the plotting of axiological positions: there is me, the opponent-obstacle, and my goal; or in the terminology of melodrama, there is the victim-hero, the villain-enemy, and the lost space of innocence that might be regained. Plotting Beck's nostalgic fantasy of simpler times in America according to such a scheme produces the following narrative logic: if we can revert to times of greater hierarchical stringency, when there was less equality among races, sexes and political views, and less potential access to power for the disenfranchised and marginalized, things would be simpler and life in America would be free of all that now ails it.

Fantasies of wholeness cathect objects with positive or negative value, thus engendering a personification of that which blocks access to wholeness. However, as wholeness is strictly a nostalgic phantasm, object cathexis can only perpetuate the fantasy, and thus the solipsistic impossible hope of regaining wholeness. Rather than seeing in cruel optimism an articulation of melodrama (which in many regards it may be) as a cultural myth, I would view melodrama as reflexively fueling cruel optimism. As myth or worldview, melodrama can help to account for the spread of misdirected, self-defeating optimism that Berlant describes. The problem is not with optimism perse, but with the manner in which historical events and societal conditions are stubbornly plotted through particular types of optimism; and at the end of the day, the optimism of melodrama is cruel.

\section{Notes}

1. Glenn Beck, Fox News Channel, 2009.

2. "The Top Talk Radio Audiences," Talkers, 24 March 2008.

3. See http://www.nab.org/documents/events/awards/ marconiAwards/2008Winners.asp, last accessed 19 January 2012.

4. "The Heavy Hundred," Talkers, 2009. 
5. See Eva Illouz, Cold Intimacies: The Making of Emotional Capitalism (Cambridge: Polity, 2007).

6. In a partial reformulation of Freudian repetition compulsion and Lacanian desire, Lauren Berlant has convincingly rearticulated this type of culturally situated cognitive-emotive reflex as an "affective structure" she calls "cruel optimism" (see Berlant's introductory chapter, "Affect in the Present," in Cruel Optimism (Durham: Duke University Press, 2011).

7. Fox News, 13 May 2010, http://www.foxnews.com/story/0,2933,592785,00. html, last accessed 20 January 2012.

8. See Linda Williams, Playing the Race Card: Melodramas of Black and White from Uncle Tom to O. J. Simpson (Princeton: Princeton University Press, 2001), and Elisabeth Anker, "Villains, Victims and Heroes: Melodrama, Media and 9/11," Journal of Communication 55:1 (March 2005): 22-37.

9. Brooks, The Melodramatic Imagination: Balzac, Henry James, Melodrama, and the Mode of Excess (New Haven: Yale University Press, 1976).

10. Brooks, The Melodramatic Imagination, 20-21.

11. Ibid., 15 .

12. Ibid., 2 .

13. Ibid., 33 and 43 .

14. Anker, "Villains, Victims and Heroes," 24.

15. See Scott Loren and Jörg Metelmann, Irritation of Life: The Subversive Melodrama of Michael Haneke, David Lynch and Lars von Trier (Marburg: Schüren, 2013), and the Introduction to this volume.

16. Anker, "Villains, Victims and Heroes," 23.

17. Julia Straub, "Melodrama and Narrative Fiction: Towards a Typology," Anglia 132:2 (2014), 225-41, here 227.

18. See Beck, The Real America: Messages from the Heart and the Heartland (New York: Pocket Books, 2005).

19. AmeriCorps is a nationally funded non-profit organization that seeks to fight illiteracy, help disadvantaged youth and "help communities respond to disasters," http://www.americorps.gov/about/ac/index.asp, last accessed 26 January 2012.

20. Beck, The Glenn Beck Program, 2 October 2009.

21. Fox News, 4 February 2009.

22. Martha Vicinus, "'Helpless and Unfriended': Nineteenth-Century Domestic Melodrama," New Literary History 13:1 (Autumn 1981), 130.

23. Williams, Playing the Race Card, 300.

24. See Christopher S. Parker, Mark Q. Sawyer and Christopher Towler, "A Black Man in the White House? The Role of Racism and Patriotism in the 2008 Presidential Election," Du Bois Review 6:1 (2009), 193-217, on how symbolic racism and patriotism have affected Obama's public reception.

25. Fox News, 28 July 2009.

26. Zaitchik, Common Nonsense: Glenn Beck and the Triumph of Ignorance (New York: John Wiley, 2010), 162. 
27. Zaitchik, Common Nonsense.

28. Ibid.; see Beck, The Real America.

29. Scientific estimates place attendance at about 87,000 ; Beck proponents claim there were up to half a million in attendance.

30. See T. Jefferson, "Glenn Beck: The Plan," http://www.glennbeck.com/content/articles/article/198/33466/, last accessed 19 February 2015.

31. See Chris Good, “Glenn Beck Comes to Town," The Atlantic, http:// www.theatlantic.com/politics/archive/2010/08/glenn-beck-comes-totown/62198/, last accessed 19 February 2015; Jason Linkins, "Glenn Beck's Decision to Scratch Plan to Promote His Book May Have Been Wise," The Huffington Post 27 August 2010, http://www.huffingtonpost.com/2010/08/27/ glenn-becks-decision-to-s_n_697242.html?view=print, last accessed 19 February 2015; and http://www.specialops.org/, last accessed 19 February 2015.

32. Sarah Palin, rally co-speaker and candidate for the vice-presidency on the Republican ticket.

33. Rev. Al Sharpton; see Huma Khan, "Conservative Commentator's Rally to be Held on Anniversary of MLK 'I Have a Dream' Speech,” ABC News, 20 August 2010, http://abcnews.go.com/print?id=11440553, last accessed $30 \mathrm{Janu}$ ary 2012.

34. See Claudia Bushman, Contemporary Mormonism: Latter-Day Saints in Modern America (Westport: Greenwood Publishing Group, 2006).

35. Peter Brooks, The Melodramatic Imagination.

36. See Joanna Brooks, "America's First Mormon Televangelist," Religion Dispatches, 31 August 2010,

http://www.religiondispatches.org/dispatches/joannabrooks/3248/america's_first_mormon_televangelist, last accessed 19 February 2015.

37. Berlant, Cruel Optimism, 51-52. 